\title{
Emergency queen rearing in honeybee colonies with brood of known age
}

\author{
Adam ToFILSKI*, Krystyna CZEKOŃSKA \\ Bee Research Department, Agricultural University, 29 Listopada 52 31-425 Krakow, Poland
}

(Received 25 April 2003; revised 14 July 2003; accepted 7 August 2003)

\begin{abstract}
In four honeybee colonies, queens were isolated on empty combs for 8 consecutive days, so that in every colony there were 8 combs containing brood of known age. Afterwards, the colonies were dequeened and the process of emergency queen rearing was observed. The average interval from egg laying to queen cell capping was 8.8 days and ranged from 7 to 12 days. The average interval from queen cell capping to queen emergence was 7.2 days and ranged from 5 to 8 days. The whole development time from egg laying to queen emergence was 15.7 days, ranging from 14 to 18 days. The age of brood at the moment of dequeening positively correlated with both the time of capping and the total queen development time. The average age of brood (at time of dequeening) around which queen cells were built was 3.0 days. However, higher proportions of queen cells with younger larvae were destroyed; in effect, the age of brood at dequeening from which queens emerged was 3.4 days.
\end{abstract}

Apis mellifera / honeybee / queen rearing / development time

\section{INTRODUCTION}

Honeybee (Apis mellifera L.) workers in queenless colonies are able to rear queens from larvae primarily destined to be workers (Winston, 1979; Fell and Morse, 1984). Larvae for queen rearing often are available in a range of ages. The reproductive quality (as defined by Tarpy et al., 2000) of queens reared from younger larvae can be higher (Eckert, 1937; Boch and Jamieson, 1960; Weaver, 1957; Woyke, 1971; Tarpy et al., 2000). On the other hand, rearing queens from older larvae can shorten the queenlessness period (Tarpy et al., 2000). Hatch et al. (1999) demonstrated that honeybee workers rear emergency queens from brood that at the time of dequeening are 1 to 5 days old. However, their experimental setup did not allow the age of brood in queen cells to be determined directly. Instead they estimated it based on the time of queen cell capping, assuming that queen cells are capped 8 days after egg laying (Winston, 1987). This type of estimation has often been used in studies of emergency queen rearing (Winston, 1979; Fell and Morse, 1984; Hatch et al., 1999; Schneider and DeGrandi-Hoffman, 2002). The accuracy of this estimation has never been determined even though it is known that the time of queen cell capping varies considerably. Jay (1963) reviewed the literature concerning the duration of queen development times, reporting that queen cells are capped between 7 and 9 days after egg laying and that the whole development time varies from 15 to 17 days. Genotype is a major factor affecting queen development time. There are marked differences between subspecies (Fletcher, 1978; Winston, 1979; DeGrandi-Hoffman et al., 1998) and some variation between colonies of the same subspecies (Visscher, 1986; Tarpy and Fletcher, 1998; Hatch et al., 1999). Even within the same colony, temperature (DeGrandi-Hoffman et al., 1993) and nutrition (Visscher, 1986) affect queen

\footnotetext{
* Corresponding author: rotofils@ @ cyf-kr.edu.pl
} 
development time. Other factors that are related to temperature and nutrition, such as the position of the queen cell in the nest (Visscher, 1986; Fell and Morse, 1984; DeGrandi-Hoffman et al., 1993; Hatch et al., 1999), affect development time as well.

Not all queen cells initiated by workers during an emergency queen rearing process successfully emerge. They can be destroyed both before and after capping (Allen, 1956; Caron and Greve, 1979; Schneider et al., 2001, 2002). The destruction of capped queen cells can be carried out by both workers and newly emerged queens (Allen, 1956; Fletcher, 1978; Caron and Greve, 1979; Gilley, 2001). Queens cut a small hole in the side wall of the queen cell and sometimes sting its occupant; workers cut a much bigger hole in the side wall and instead of stinging they remove the contents of the queen cell (Allen, 1956; Fletcher, 1978; Caron and Greve, 1979). Hatch et al. (1999) did not allow newly emerged queens to walk freely in the nest and destroy unemerged competitors in queen cells. Isolation of queen cells can affect the chances of queens being reared from brood of different ages, and in consequence, affect the reproductive quality of the only queen remaining in a colony when the process of emergency queen rearing is finished. Thus, to fully evaluate the factors influencing queen rearing, it is necessary to examine queen replacement under natural conditions in colonies containing brood of known age.

The purpose of this paper was to investigate emergency queen rearing in honeybee colonies. We had two main objectives. First, we determined the variability of the different stages of queen development and the accuracy of estimation of ages of brood in queen cells based on their time of capping. Second, we measured more accurately than previous studies the ages of brood from which emergency queens are produced. We examined the process of emergency queen rearing in colonies in which the age of young brood is known and newly emerged queens have access to unemerged queen cells.

\section{MATERIALS AND METHODS}

The experiment was carried out in June and July 2000 , and used four colonies of honeybees consid-

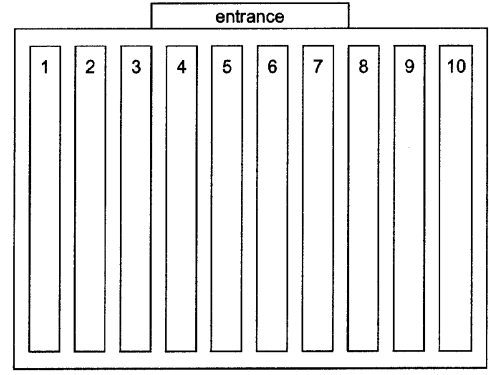

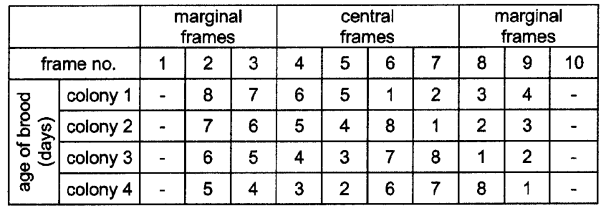

Figure 1. Arrangement of frames with brood of different ages in four experimental colonies.

ered to be Apis mellifera carnica. The colonies were of similar size, and each occupied two boxes containing 10 frames apiece. The frames were of the wielkopolski type locally used in Poland (width $360 \mathrm{~mm}$, height $260 \mathrm{~mm}$ ). To obtain eggs of known age, the queen from each colony was confined for 24 hours on an empty frame of comb in a cage made of wood and queen excluder. The caged queens were placed in their original colonies in the center of the bottom box. This procedure was repeated 8 times. Every day the queens were isolated on new frames of empty comb. At the end of the procedure all colonies were dequeened. At that time in the bottom box of each hive there were 8 combs containing brood ranging in age from 1-day old eggs to 5-day old larvae. The other two frames in the bottom box and the frames in the upper box contained brood older than 8 days, honey and pollen stores. The combs with brood of different ages were placed in a different order in each colony (Fig. 1). After removal of the queens, the colonies were examined every day at the same time of day until all queen cells were either emerged or destroyed. During inspections the position of every queen cell was marked on acetate sheets, one sheet for each side of each frame. If a regular round opening was found at the bottom of the queen cell it was categorized as emerged. If an opening was found in the side of the queen cell it was categorized as destroyed. We call the interval from egg laying to queen cell capping the precapping period, and the interval from queen cell capping to queen emergence the postcapping period.

In the statistical analysis we combined the data from all four colonies because we were more interested in variation within the population than in 
differences between colonies. The times of queen cell initiation, queen cell capping and queen emergence were analyzed in relation to both the time of dequeening and the time of egg laying. Associations between two variables (e.g., length of precapping period and distance from the bottom of the hive) were tested with Spearman's rank correlation. Differences between all continuous variables (e.g., length of precapping period) and discontinuous variables (e.g., number of queen cells) were analyzed using nonparametric tests: the Mann-Whitney test in the case of two groups and the Kruskal-Wallis test when there were more than two groups. The proportions of queen cells destroyed were analyzed using the G-test of independence (Sokal and Rohlf, 1995). The G-test cannot be calculated for frequency equal to zero, so the numbers of emerged and destroyed queen cells were combined across ages 6 to 8 days. All average values are reported as $\pm 1 \mathrm{SD}$.

\section{RESULTS}

\subsection{General information}

The numbers of initiated, capped and emerged queen cells per colony were $32.7 \pm 4.79,27.0 \pm$ 1.83 and $13.0 \pm 1.63(\mathrm{~N}=4)$, respectively. The numbers of queen cells on central and marginal frames were $19.0 \pm 2.45$ and $13.7 \pm 2.63(\mathrm{~N}=$ 4 ), respectively. Those values differ significantly (Mann-Whitney test: $\mathrm{U}=0.5, \mathrm{~N}_{1}=\mathrm{N}_{2}=$ $4, P=0.028)$. The frame area covered by brood was $1.55 \pm 0.55 \mathrm{dm}^{2}(\mathrm{~N}=32)$, ranging from 0.20 to $2.76 \mathrm{dm}^{2}$. There was no significant correlation between the frame area covered by brood and the number of queen cells on the frame (Spearman's rank correlation: $\mathrm{r}_{\mathrm{s}}=0.208, \mathrm{~N}=$ $32, P=0.254)$. The brood area did not differ between frames of different brood age (KruskalWallis test: $\mathrm{H}=5.18, \mathrm{df}=7, \mathrm{~N}=32, P=0.638$ ), nor between central and marginal frames (MannWhitney test: $\mathrm{U}=126, \mathrm{~N}_{1}=\mathrm{N}_{2}=16, P=0.940$ ).

\subsection{Precapping period}

The queen cell precapping period was $8.8 \pm$ 1.30 days $(\mathrm{N}=108)$ and ranged from 7 to 12 days (Fig. 2B). Queen cells from which queens emerged were capped at a slightly, but significantly earlier age $(8.5 \pm 1.08$ days; $\mathrm{N}=52)$ than those that were destroyed $(9.1 \pm 1.43$ days; $\mathrm{N}=56$ ) (Mann-Whitney test: $\mathrm{U}=1114, \mathrm{~N}_{1}=$ $52, \mathrm{~N}_{2}=56, P=0.020$; Fig. 2B). The precapping period of queen cells from which queens emerged positively correlated with the age of

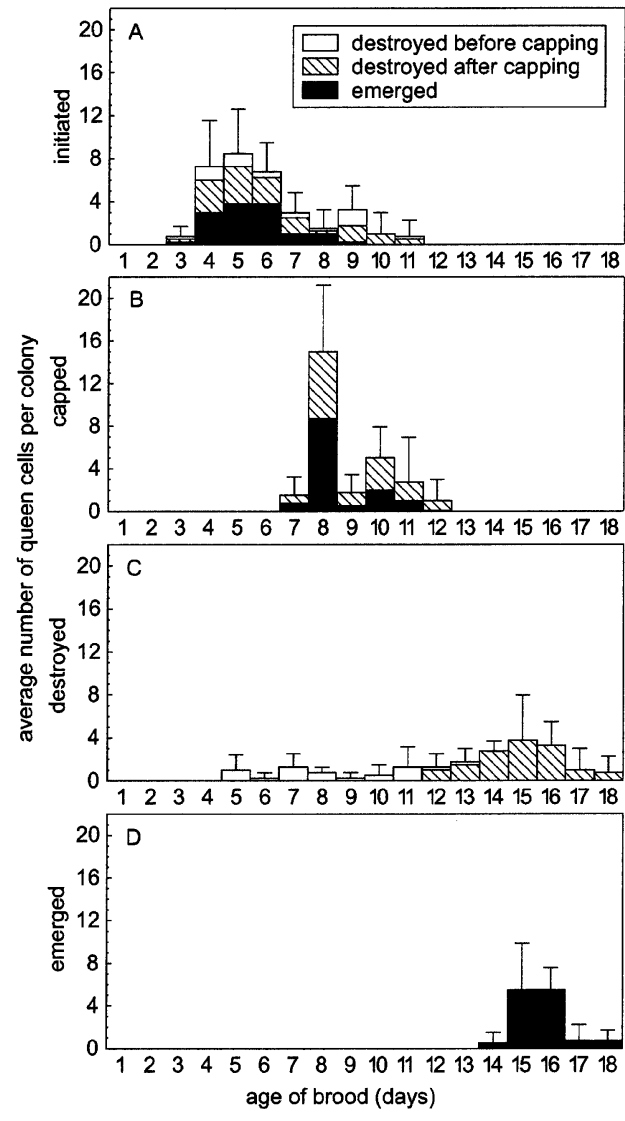

Figure 2. Distribution of ages of brood around which queen cells were built (A), distribution of ages of brood at time of queen cell capping (B), distribution of ages of brood at time of queen cell destruction (C), and distribution of whole development times from egg laying to queen emergence (D) during emergency queen rearing. Bars represent averages $+\mathrm{SD}$ across four colonies.

brood at the time of dequeening (Spearman's rank correlation: $\mathrm{r}_{\mathrm{S}}=0.555, \mathrm{~N}=52, P<0.001$; Fig. 3A) and with the distance of the queen cell from the central frame (Spearman's rank correlation: $\mathrm{r}_{\mathrm{s}}=0.317, \mathrm{~N}=52, P=0.022$ ). The precapping period negatively correlated with the distance of the queen cell from the bottom of the hive (Spearman's rank correlation: $\mathrm{r}_{\mathrm{s}}=$ $-0.304, \mathrm{~N}=108, P=0.001$ ), but this relationship was not significant when only queen cells from which queens emerged were analyzed (Spearman's rank correlation: $\mathrm{r}_{\mathrm{S}}=-0.141, \mathrm{~N}=$ $52, P=0.318)$. The precapping period negatively correlated with the postcapping period 

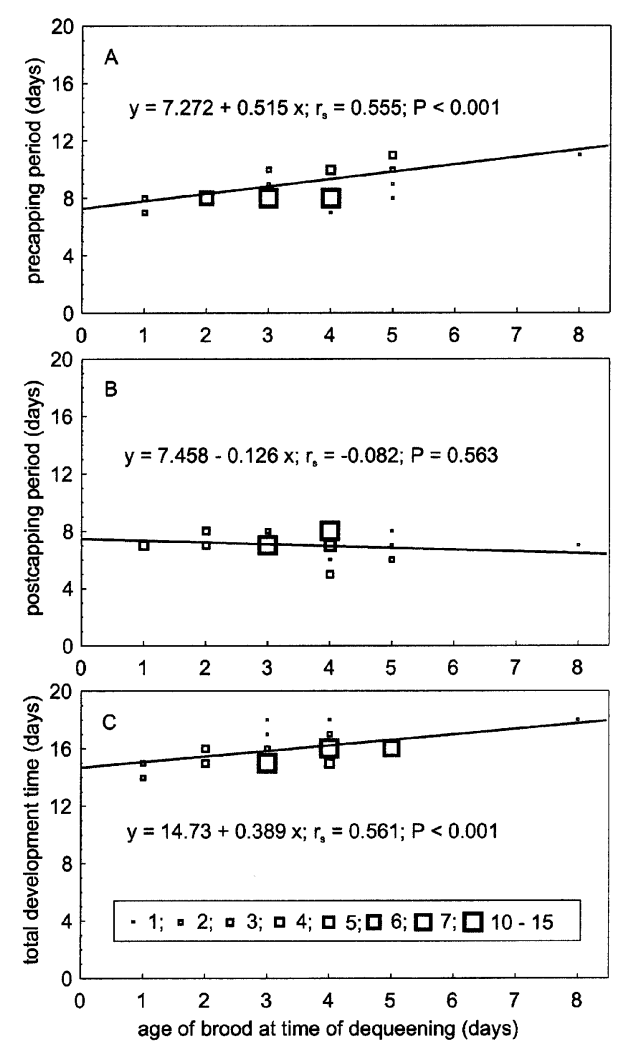

Figure 3. Relationship between age of brood at time of dequeening and different stages of queen development. Only data from emerged queen cells were included. Sizes of squares correspond to number of observations.

(Spearman's rank correlation: $\mathrm{r}_{\mathrm{S}}=-0.432, \mathrm{~N}=$ $52, P=0.001)$. The precapping period of queens reared from brood, which was younger at the time of dequeening, tended to be shorter than the precapping period of queens reared from older brood. The queen cells in the center of the nest tended to be capped after a shorter period of time than the queen cells at the nest periphery.

\subsection{Postcapping period}

The postcapping period was $7.2 \pm 0.78$ days $(\mathrm{N}=52)$ and ranged from 5 to 8 days (Fig. 3B). The postcapping period negatively correlated with the distance of the queen cell from the central frame (Spearman's rank correlation: $\left.\mathrm{r}_{\mathrm{s}}=-0.311, \mathrm{~N}=52, P=0.025\right)$. There was no significant relationship between the postcapping period and the age of brood at the time of dequeening (Spearman's rank correlation: $\mathrm{r}_{\mathrm{s}}=$ $-0.082, \mathrm{~N}=52, P=0.563$; Fig. 3B) and the distance of the queen cell from the bottom of the hive (Spearman's rank correlation: $r_{\mathrm{s}}=$ $0.172, \mathrm{~N}=32, P=0.222$ ). The postcapping period of queens reared in the center of the nest tended to be longer than the postcapping period of queens reared at the nest periphery but was not affected by the age of brood at the time of dequeening.

\subsection{Total development time}

Queen emergence occurred between 14 and 18 days after the egg was laid, with an average of $15.7 \pm 0.88$ days $(\mathrm{N}=52$; Fig. 2D). The total development time positively correlated with the age of brood at the time of dequeening (Spearman's rank correlation: $\mathrm{r}_{\mathrm{s}}=0.561, \mathrm{~N}=$ $52, P<0.001$; Fig. 3C). There was no significant relationship between the total development time and the distance of the queen cell from the central frame (Spearman's rank correlation: $\left.\mathrm{r}_{\mathrm{s}}=0.118, \mathrm{~N}=52, P=0.406\right)$ and the distance of the queen cell from the bottom of the hive (Spearman's rank correlation: $\mathrm{r}_{\mathrm{s}}=$ $-0.017, \mathrm{~N}=52, P=0.904)$. The total development time of queens reared from brood that was younger at the time of dequeening tended to be shorter than the total development time of queens reared form older brood, but did not depend on the position of the queen cells in the nest.

\subsection{Initiation and destruction of queen cells}

The queen cells were initiated around brood aged between 3 and 11 days; the average age of brood used to initiate queen cells was $5.9 \pm$ 1.90 days $(\mathrm{N}=131$; Fig. 2A). Eggs were never observed inside queen cells. Queen cells from which queens emerged and those destroyed either before or after capping did not differ in the age of brood from which they were constructed (Mann-Whitney test: $\mathrm{U}=1732, \mathrm{~N}_{1}=$ $52, \mathrm{~N}_{2}=79, P=0.123$; Fig. 2A). Most of the queen cells $(60.3 \%)$ were destroyed, $17.6 \%$ of them before capping and $42.7 \%$ after capping (Fig. 2C). The queen cells were destroyed between the 5th and 18th days of brood development, and the average age of brood at the time of queen cell destruction was $13.0 \pm 3.48$ days $(\mathrm{N}=79$; Fig. $2 \mathrm{C})$. A smaller 


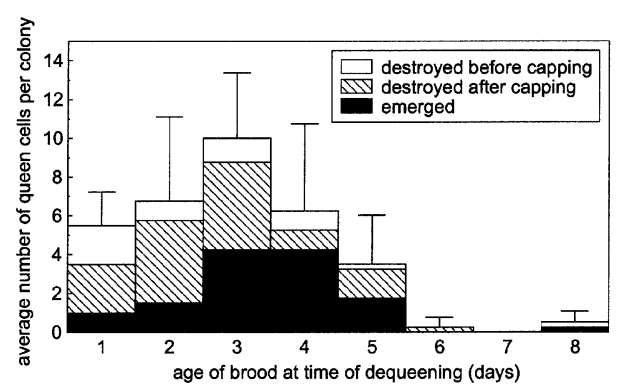

Figure 4. Distribution of ages of brood (at time of dequeening) from which queen cells were built. Bars represent averages + SD across four colonies.

proportion of queen cells were destroyed on central frames $(51.3 \%)$ than on marginal frames $(72.7 \%$; G-test of independence: $\mathrm{G}=$ $6.17, \mathrm{df}=1, P=0.013)$.

\subsection{Use of brood of different ages}

The age (at time of dequeening) of brood around which queen cells were built and from which queens emerged was $3.0 \pm 1.40(\mathrm{~N}=131)$ and $3.4 \pm 1.27(\mathrm{~N}=52)$ days, respectively (Fig. 4). Queen cells from which queens emerged were initiated using brood that was older at the time of dequeening $(3.4 \pm 1.27$ days; $\mathrm{N}=52$ ) than the brood of those destroyed either before or after capping $(2.7 \pm 1.40$ days; $\mathrm{N}=$ 79) (Mann-Whitney test: $U=1327, N_{1}=52$, $\mathrm{N}_{2}=79, P<0.001$; Fig. 4). The age of brood at the time of dequeening significantly affected the number of queen cells constructed using the brood (Kruskal-Wallis test: $\mathrm{H}=21.2, \mathrm{df}=7$, $\mathrm{N}=32, P<0.004$; Fig. 4). The greatest number of queen cells were constructed over brood 3 days old at the time of dequeening (Fig. 4). The age of brood at the time of dequeening also affected the proportion of queen cells destroyed (G-test of independence: $\mathrm{G}=17.0, \mathrm{df}=5, P=$ 0.005 ; Fig. 4). The smallest proportion of queen cells were destroyed on frames with brood 4 days old at the time of dequeening (Fig. 4).

\subsection{Emergency queen rearing in relation to time of dequeening}

Queen cells were initiated between the 1st and 9 th days after dequeening (Fig. 5A). In two of the colonies the first queen cells were observed the day after dequeening, and in the other two colonies the second day after

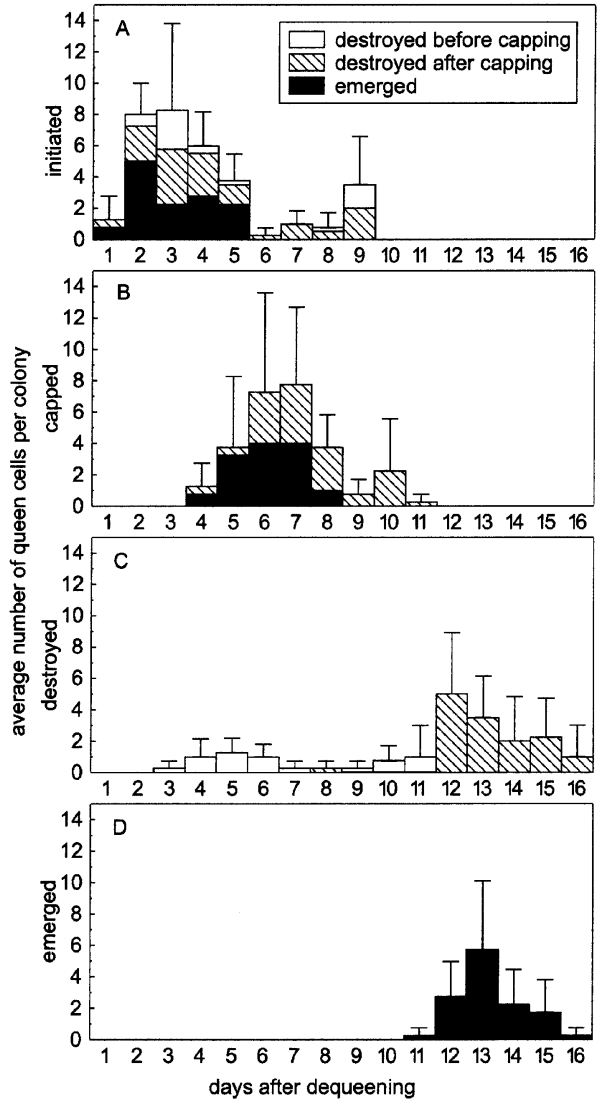

Figure 5. Timing of rebuilding of worker cells into queen cells (A), capping of queen cells (B), destruction of queen cells (C), and queen emergence (D) during emergency queen rearing. Bars represent averages $+\mathrm{SD}$ across four colonies.

dequeening. Queen cells from which queens emerged were initiated significantly earlier than those destroyed either before or after capping (Mann-Whitney test: $\mathrm{U}=1372, \mathrm{~N}_{1}=52$, $\mathrm{N}_{2}=79, P=0.001$; Fig. 5A). The distribution of times at which queen cells were initiated was bimodal, with the first mode on the 2nd-3rd day after dequeening and the second mode on the 9th day after dequeening (Fig. 5A). The queen cells were capped between the 4th and 11th days after dequeening, and the peak of queen cell capping occurred the 6th-7th day after dequeening (Fig. 5B). The queen cells from which queens emerged were sealed significantly earlier than those destroyed after capping (Mann-Whitney test: $\mathrm{U}=752, \mathrm{~N}_{1}=52$, $\mathrm{N}_{2}=56, P<0.001$; Fig. 5B). Queens emerged 
from the queen cells between the 11th and 16th days after dequeening, and the peak of queen emergence occurred the 13th day after dequeening (Fig. 5D). Queens reared from brood older at the time of dequeening tend to emerge earlier than queens reared from younger brood (Spearman's rank correlation: $\left.\mathrm{r}_{\mathrm{s}}=-0.758, \mathrm{~N}=52, P<0.001\right)$. Destruction of queen cells was observed between the 3rd and 16th days after dequeening (Fig. 5C). The distribution of times at which queen cells were destroyed was bimodal, with the first mode on the 4th-6th day after dequeening and the second on the 12th day after dequeening (Fig. 5C).

\section{DISCUSSION}

Our data show that both the precapping period and the whole development time of emergency queens increase with the age of brood from which the queens were reared (Fig. 3). Thus, estimations of brood age in emergency queen cells based on time of capping (Winston, 1979; Fell and Morse, 1984; Hatch et al., 1999; Schneider and DeGrandi-Hoffman, 2002) cannot be very accurate. Another source of inaccuracy of estimations is the correlation of the precapping period with the position of the queen cell in the nest (Visscher, 1986; Fell and Morse, 1984; DeGrandi-Hoffman et al., 1993; Hatch et al., 1999). Both the distance from the central frame and the distance from the bottom of the nest affected the length of the precapping period in this study. The differences in the length of the precapping period of brood in queen cells positioned in different parts of the nest are compensated by the length of the postcapping period. In consequence the whole development time does not depend on the position of the queen cell in the nest. Bienefeld (1996) observed a similar negative correlation between the precapping and postcapping periods in honeybee workers.

Estimating age of brood in queen cells on the assumption that the precapping period is always 8 days often results in underestimations of brood age. In the majority of cases the underestimation is low compared to the error of one day accepted by most studies of emergency queen rearing (Hatch et al., 1999; Schneider and DeGrandi-Hoffman, 2002). For the average age of brood used to produce queens in this study (2.96 days; Fig. 4), the difference between the estimated and actual precapping period (calculated using linear regression coefficients; Fig. 3A) was 0.80 days. However, some of the queen cells were capped 12 days after egg lying (Fig. 2B). In those rare (3\%) cases the error of estimation of the age of brood in queen cells can reach four days. During swarming, all queen cells are initiated with newly laid eggs, so brood age estimations based on the time of capping can then be much more accurate, although this needs to be verified experimentally. Other factor affecting the accuracy of the estimation will be the position of the queen cell in the nest. Our results suggest that the whole development time, instead of the time of capping, should be used for estimation because it does not depend on the position of the queen cell in the nest.

We studied emergency queen rearing under natural conditions and did not isolate the capped queen cells. This means that the time of emergence of queens was affected not only by the age of brood (at time of dequeening) and the position of queen cells in the nest but also by other factors that can influence queen emergence and which may differ between emergency queen rearing and swarming. Workers standing on queen cells often perform a vibration signal, which consists of dorsoventral vibration of their body (Allen, 1959; PainterKurt and Schneider, 1998). It has been suggested that the vibration signal affects timing of queen emergence (Fletcher, 1978; Bruinsma et al., 1981; but see Grooters, 1987; Schneider et al., 2001) and inhibits interactions between queens (Fletcher, 1978; Schneider, 1990, 1991). Moreover, emerged queens produce a series of pulsed sounds called piping which can delay the emergence of other queens (Grooters, 1987). Piping is more common during swarming than during emergency queen rearing (personal observations). A factor probably limited to swarming periods is imprisonment of young queens in queen cells (Fletcher, 1978; Bruinsma et al., 1981). The mentioned factors may influence the timing of queen emergence and thus may have affected the positive relationship between age of brood (at time of dequeening) and the total development time. Other experimental setups and particularly isolation of capped queen cells in an incubator can influence the length of different stages of queens development. This has to be taken into account when the data presented here are compared with results of other studies. 
The average lengths of different stages of honeybee queen development from our study agree with those from other studies (Jay, 1963; Winston, 1987), but the variation was greater in our experiment (Fig. 2). The large variation can be explained partly by differences in measurement accuracy, which in our study was affected by the length of time between consecutive queen cell inspections ( $24 \mathrm{~h}$ ) and also by the length of time provided for queens to lay eggs in a single frame of comb (24 h). It is difficult to obtain higher accuracy of brood age measurements in a full-size colony, because frequent inspections disturb it and can affect the results.

We showed that workers initiate queen cells using brood in a wide range of ages at dequeening, but the greatest number of queen cells were produced around brood that at the time of dequeening were 3 days old (Fig. 4). Hatch et al. (1999) reported a similar pattern of queen cell initiation, but the range of ages used to produce queen cells was narrower in their study. This discrepancy is probably due to inaccurate estimates of brood age, based on the time of queen cell capping. Even though newly emerged queens are able to destroy other queen cells, in our experiment a considerable number of queens emerged in each of the colonies. Either workers protected the queen cells from destruction (Gilley, 2001) or the early emerged queens could not find and destroy the remaining queen cells before the queens emerged from them. Because queen cells with younger brood are more often destroyed, the average age of brood (at time of dequeening) from which queens emerged was higher than the average age of brood (at time of dequeening) around which queen cells were built (Fig. 4). We did not observe queen cell destruction in progress; another experiment is needed to determine whether the queen cells with younger brood were destroyed by newly emerged queens or workers. This problem needs to be addressed so that the mechanisms by which the quality of emergency queens is controlled in honeybee colonies can be better understood.

\section{ACKNOWLEDGMENTS}

We thank Michael Jacobs, Luis Medina Medina, Stanley Schneider and two anonymous referees for helpful comments on earlier versions of this paper.
Résumé - Production de reines de remplacement dans des colonies d'abeilles (Apis mellifera) dont l'âge du couvain est connu. Dans les colonies d'abeilles orphelines les ouvrières sont capables d'élever des reines de remplacement à partir de larves qui étaient destinées à devenir des ouvrières. Dans les études précédentes sur la production des reines de remplacement, l'âge du couvain choisi par les ouvrières était estimé d'après le moment où avait eu lieu l'operculation de la cellule royale. Le but de cette étude était (i) de déterminer la précision de l'estimation de l'âge du couvain dans les cellules royales et (ii) de mesurer l'âge des larves à partir desquelles les reines de remplacement étaient élevées. Dans quatre colonies on a isolé les reines sur un rayon vide chaque jour durant $8 \mathrm{j}$ consécutifs. Il y avait donc dans chaque colonie 8 rayons renfermant du couvain d'âge connu. Après avoir ôté les reines, on a examiné journellement et noté la position et la condition de chaque cellule royale. L'intervalle entre la ponte et l'operculation de la cellule royale était comprise entre 7 et $12 \mathrm{j}$, avec une moyenne de $8,8 \mathrm{j}$ (Fig. 2B). La reine a éclos 7,2 j plus tard, en moyenne (Fig. 3B). La corrélation entre ces deux durées de développement était négative. La durée totale de développement de la ponte à l'éclosion de la reine était comprise entre 14 et $18 \mathrm{j}$, avec une moyenne de $15,7 \mathrm{j}$ (Fig. 2D). L'âge du couvain au moment de l'orphelinage était corrélé positivement avec la durée de la période pré-operculation et la durée totale de développement (Fig. 4). Au moment de l'orphelinage, le couvain autour duquel les cellules royales étaient construites avait un âge moyen de 3,0 j. Pourtant les cellules royales possédant des larves plus jeunes ont été détruites en plus grand nombre ; au moment de l'orphelinage, l'âge des larves d'où sont sorties les reines était de $3,4 \mathrm{j}$ (Fig. 4). Ce résultat montre que l'estimation de l'âge du couvain basée sur la période de pré-operculation ne peut pas être très précise.

\section{Apis mellifera / élevage de reines / durée de développement}

Zusammenfassung - Erzeugung von Nachschaffungsköniginnen in Bienenvölkern mit Brut bekannten Alters. Honigbienen in weisellosen Völkern können Nachschaffungsköniginnen aus Larven nachziehen, diese werden von den Arbeiterinnen bestimmt. In früheren Untersuchungen wurde das Alter der von den Arbeiterinnen zur Königinnenerzeugung ausgesuchten Larven aus dem Zeitpunkt der Verdeckelung der Königinnenzellen geschätzt. Das Ziel dieser Untersuchung war, das Alter der Brut zu messen, aus der die Nachschaffungszellen erzeugt werden und hieran weiterhin die Genauigkeit der bisherigen Altersschätzung zu überprüfen. In vier Bienenvölkern wurden die Königinnen an acht aufeinanderfolgenden Tagen auf leere Waben gesperrt, hierdurch befanden sich in jedem Volk 8 Waben mit Brut bekannten Alters. Nach Entfernung der 
Königinnen wurden die Völker jeden Tag untersucht und die Lage und der Zustand jeder entstehenden Nachschaffungszelle notiert. Das mittlere Zeitintervall zwischen der Eilage und der Verdeckelung der Königinnenzellen betrug 8,8 Tage, es schwankte zwischen 7 und 12 Tagen (Abb. 2B). Danach dauerte es im Mittel weitere 7,2 Tage bis die Königinnen schlüpften (Abb. 3B). Diese zwei Entwicklungszeiten korrelierten negativ und die gesamte Entwicklungszeit von der Eilage bis zum Schlupf der Königinnen betrug 15,7 Tage, es schwankte zwischen 14 und 18 Tagen (Abb. 2D). Das Alter der Brut zum Zeitpunkt der Entweiselung korrelierte positiv sowohl mit der Dauer der Zeit vor der Verdeckelung als auch mit der gesamten Entwicklungsdauer (Abb. 4). Zum Zeitpunkt derEntweiselung betrug das Alter der Brut, aus der die Nachschaffungszellen erzeugt wurden, 3,0 Tage. Allerdings wurden größere Anzahlen der aus jüngerer Brut erzeugten Königinnenzellen zerstört, hierdurch betrug das Alter der Larven aus denen tatsächlich Königinnen schlüpften, beim Entweiseln der Völker 3,4 Tage (Abb. 4). Die Ergebnisse zeigen, dass die auf der Zeit bis zum Verdeckeln der Zellen beruhenden Altersschätzungen der Larven nicht sehr genau sein können.

\section{Apis mellifera / Honigbienen / Königinnenerzeu- gung / Entwicklungsdauer}

\section{REFERENCES}

Allen M.D. (1956) The behavior of honeybees preparing to swarm, Brit. J. Anim. Behav. 4, 14-22.

Allen M.D. (1959) The occurrence and possible significance of the 'shaking' of honeybee queens by workers, Anim. Behav. 7, 66-69.

Bienefeld K. (1996) Factors affecting duration of the postcapping period in brood of the honey bee, $\mathrm{J}$. Apic. Res. 35, 11-17.

Boch R., Jamieson C.A. (1960) Relation of body weight to fecundity in queen honeybees, Can. Entomol. 92, 700-701.

Bruinsma O., Kruijt J.P., van Dusseldorp W. (1981) Delay of emergence of honey bee queens in response to tooting sounds, Proc. K. Ned. Akad. van Wet., Series C 84, 381-387.

Caron D.M., Greve C.W. (1979) Destruction of queen cells placed in queenright Apis mellifera colonies, Ann. Entomol. Soc. Am. 72, 405-407.

DeGrandi-Hoffman G., Spivak M., Martin J.H. (1993) Role of thermoregulation by nestmates on the development time of honey bee (Hymenoptera: Apidae) queens, Ann. Entomol. Soc. Am. $86,165-172$.

DeGrandi-Hoffman G., Watkins J.C., Collins A.M., Loper G.M., Martin J.H., Arias M.C., Sheppard W.S. (1998) Queen developmental time as a factor in the Africanization of European honey bee (Hymenoptera: Apidae) populations, Ann. Entomol. Soc. Am. 91, 52-58.

Eckert J.E. (1937) Relation of size to fecundity in queen honeybees, J. Econ. Entomol. 30, 646-648.
Fell R.D., Morse R.A. (1984) Emergency queen cell production in the honey bee colony, Insectes Soc. 31, 221-237.

Fletcher D.J.C. (1978) The African bee, Apis mellifera adonsoni, in Africa, Annu. Rev. Entomol. 23,151-171.

Gilley D.C. (2001) The behavior of honey bees (Apis mellifera ligustica) during queen duels, Ethology 107, 601-622.

Grooters H.J. (1987) Influences of queen piping and worker behaviour on the timing of emergence of honey bee queens, Insectes Soc. 34, 181-193.

Hatch S., Tarpy D.R., Fletcher D.J.C. (1999) Worker regulation of emergency queen rearing in honey bee colonies and the resultant variation in queen quality, Insectes Soc. 46, 372-377.

Jay S.C. (1963) The development of honeybee in their cells, J. Apic. Res. 2, 117-134.

Painter-Kurt S., Schneider S.S. (1998) Age and behaviour of honey bees, Apis mellifera (Hymenoptera: Apidae), that perform vibration signals on queens and queen cells, Ethology 104, 475-485.

Sokal R.R., Rohlf F.J. (1995) Biometry, W.H. Freeman, New York.

Schneider S.S. (1990) Queen behaviour and workerqueen interactions in absconding and swarming colonies of the African honey bee, Apis mellifera scutellata (Hymenoptera: Apidae), J. Kans. Entomol. Soc. 63, 179-186.

Schneider S.S. (1991) Modulation of queen activity by the vibration dance in swarming colonies of the African honey bee, Apis mellifera scutellata (Hymenoptera: Apidae), J. Kans. Entomol. Soc. 64, 269-278.

Schneider S.S., DeGrandi-Hoffman G. (2002) The influence of worker behavior and paternity on the development and emergence of honey bee queens, Insectes Soc. 49, 306-314.

Schneider S.S., Painter-Kurt S., DeGrandi-Hoffman G. (2001) The role of the vibration signal during queen competition in colonies of the honeybees, Apis mellifera, Anim. Behav. 61, 1173-1180.

Tarpy D.R., Fletcher D.J.C. (1998) Effects of relatedness on queen competition within honey bee colonies, Anim. Behav. 55, 537-543.

Tarpy D.R., Hatch S., Fletcher D.J.C (2000) The influence of queen age and quality during queen replacement in honeybee colonies, Anim. Behav. 59, 97-101.

Visscher P.K. (1986) Effect of location within the nest on acceptance of queen cells in honeybee colonies, J. Apic. Res. 25, 154-157.

Weaver N. (1957) Effects of larval age on dimorphic differentiation of the female honeybee, Ann. Entomol. Soc. Am. 50, 283-294.

Winston M.L. (1979) Events following queen removal in colonies of Africanized honeybees in South America, Insectes Soc. 26, 373-381.

Winston M.L. (1987) The biology of the honey bee, Harvard University Press, Cambridge, London.

Woyke J. (1971) Correlations between the age at which honeybee brood was grafted, characteristics of the resultant queens, and results of insemination, J. Apic. Res. 10, 45-55. 